Canadian

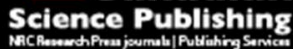

Canadian Geotechnical Journal Revue canadienne de géotechnique

\title{
Urease active bio-slurry: a novel soil improvement approach based on microbially induced carbonate precipitation
}

\begin{tabular}{|r|l|}
\hline Journal: & Canadian Geotechnical Journal \\
\hline Manuscript ID & cgj-2015-0635.R1 \\
\hline Manuscript Type: & Article \\
\hline Date Submitted by the Author: & 11 -Mar-2016 \\
\hline Complete List of Authors: & $\begin{array}{l}\text { Cheng, Liang; Murdoch Univ, ; Curtin University, Civil Engineering } \\
\text { Shahin, Mohamed; Curtin University, Civil Engineering }\end{array}$ \\
\hline Keyword: & $\begin{array}{l}\text { Bio-slurry, microbially induced carbonate precipitation (MICP), bio- } \\
\text { cementation, ground improvement, soil stabilization }\end{array}$ \\
\hline \multicolumn{2}{|l}{} \\
\hline
\end{tabular}

SCHOLARONE ${ }^{\mathrm{Im}}$

Manuscripts 


\section{Urease active bio-slurry: a novel soil improvement approach based on microbially} induced carbonate precipitation

4 Liang Cheng: Postdoctoral Research Fellow, Department of Civil Engineering, Curtin

5 University, Kent Street, Bentley, Perth, Western Australia 6102. Email:

$6 \quad$ liang.cheng@curtin.edu.au.Tel: +61(0)892664538

7 Mohamed A. Shahin: Associate Professor, Department of Civil Engineering, Curtin

8 University, Kent Street, Bentley, Perth, Western Australia 6102. Email:

$9 \quad$ m.shahin@,curtin.edu.au.Tel: +61(0)892661822

10 Corresponding author: Liang Cheng, Department of Civil Engineering, Curtin University,

11 Kent Street, Bentley, Perth, Western Australia 6102. Email: liang.cheng@.curtin.edu.au.Tel:

$12+61(0) 892664538$

13 This paper was written on 16 Dec 2015 and submitted to Canadian Geotechnical Journal 


\section{Urease active bio-slurry: a novel soil improvement approach based on microbially}

\section{5 induced carbonate precipitation}

16 Liang Cheng and Mohamed A. Shahin

\section{Abstract:}

18 This paper presents a novel approach for soil stabilization by microbially induced carbonate 19 precipitation (MICP) using a new urease active catalyzer named herein as "bio-slurry". The 20 bio-slurry, which was produced from reaction between bacterial culture and $400 \mathrm{mM}$ of $21 \mathrm{CaCl}_{2}$ and Urea, is pre-formed urease active crystals consisting of $\mathrm{CaCO}_{3}$ plus imbedded 22 urease active bacterial cells. By mixing the bio-slurry with sand, more than $95 \%$ of the bio23 slurry was retained in the soil matrix as a result of the mechanical trapping mechanism, 24 leading to high resistance to flushing of low salinity solution. The retained urease activity of 25 bio-slurry was uniformly distributed along the sand matrix, resulting in a rather uniform $26 \mathrm{CaCO}_{3}$ precipitation. Through repeated treatments with cementation solution, the unconfined 27 compressive strength of bio-slurry treated sand was significantly improved due to the 28 effective $\mathrm{CaCO}_{3}$ precipitation at the contact points of soil grains. Scanning electron 29 microscopy analysis carried out on the bio-slurry treated sand revealed that the induced large 30 rhombohedral $\mathrm{CaCO}_{3}$ crystals were localized around the bio-slurry spherical fine crystals.

31 The overall outcome of this work is that soil biocementation using the new bio-slurry 32 approach is controllable, reproducible and homogeneous.

33 Keywords: Bio-slurry; microbially induced carbonate precipitation (MICP); bio34 cementation; ground improvement; soil stabilization. 


\section{Introduction}

36 Over the years, the growth of human population has rendered the construction on weak soils

37 inescapable (Ng et al. 2012). Current remedial methods for ground improvement include soil

38 replacement, chemical stabilization by grouts, mechanical stabilization by compaction,

39 consolidation by drainage, reinforcement with steel or geosynthetics, and use of electro-

40 osmosis. Among these methods, chemical stabilization by grouts is widely employed, where

41 the mineralogical structure of soil is altered by chemical additives (e.g. cement or lime) to

42 improve the physical and mechanical engineering properties of soil. However, chemical

43 grouts can cause serious environmental problems and contribute to ecosystem disturbance

44 and thus are considered to be hazardous (Soon et al. 2014). In fact, initiatives in several

45 countries, such as the USA, have proposed to ban most synthetic grouting materials (DeJong

46 et al. 2010) both because of their toxicity and due to a desire to reduce cement use as this is a

47 major contributor to global anthropogenic carbon dioxide emissions. As there are more than

4840,000 projects/year performed worldwide employing chemically stabilized soils at a total

49 cost exceeding US\$6 billion, there is an immense need for alternative environmentally-

50 friendly and sustainable technologies that can fulfil the increasing demand for ground

51 improvement (DeJong et al. 2010; Ng et al. 2012; Achal and Mukherjee 2015).

52 An emerging soil stabilization method, known as microbially induced carbonate precipitation

53 (MICP) utilizing the concept of bio-mineralization, has been recently proposed as an

54 alternate, environmentally safe ground improvement technology. This technique is relatively

55 new in geotechnical engineering but has been potentially promising in terms of its capability

56 of improving the engineering properties of soil while preserving environmental sustainability

57 (Whiffin et al. 2007). MICP uses the metabolic pathways of ureolytic bacteria to form

58 calcium carbonate precipitation throughout the soil matrix, thereby, strengthening the soil 
59 strength and stiffness while being able to retain sufficient permeability which is favored for

60 many geotechnical engineering applications.

61 One of the main intrinsic obstacles of MICP technology as a practical ground improvement 62 methodology is the uniformity of $\mathrm{CaCO}_{3}$ formation and corresponding mechanical strength 63 achieved, which are due to the non-uniform transport and attachment of bacteria to the 64 surface of soil particles. Several attempts have been found in the literature to overcome this 65 problem. For example, Stocks-Fischer et al. (1999) found that the injection of bacteria and 66 reagents together at lower rates can result in a full clogging of the system near the injection 67 point. Whiffin et al. (2007) developed a two-phase injection method, whereby one pore volume of bacterial suspension was used followed by one pore volume of $50 \mathrm{mM} \mathrm{CaCl} 2$ solution before injecting the cementation solution. Although the results showed that it was possible to precipitate $\mathrm{CaCO}_{3}$ at a distance of $5 \mathrm{~m}$, the $\mathrm{CaCO}_{3}$ content and consequent mechanical behavior were not homogeneously distributed over the tested sand column. The feasibility of such treatment method was further demonstrated in a large-scale trial $\left(100 \mathrm{~m}^{3}\right)$ by Van Paassen et al. (2010); however, the outcomes indicated varied strength of products

74 from loosely cemented sand to moderately strong rock with varied unconfined compressive strength (UCS) between 0.7 and $12 \mathrm{MPa}$ as a result of the non-uniform distribution of $\mathrm{CaCO}_{3}$ precipitation. Feng and Montoya (2015) tested the behavior of sand treated with MICP under confined pressure using the two-phase injection method and the results indicated a nonuniform calcium carbonate distribution along the tested sand column (scale of $\mathrm{cm}$ ), especially after heavy cementation (i.e. $>4 \%$ calcium carbonate with variation more than $40 \%$ ). Similar

80 heterogeneity of cementation distribution was also reported by Martinez et al. (2013). More recently, Cheng and Cord-Ruwisch (2014) has developed a new treatment method that relies on surface percolation to apply bacteria and cementation solution into unsaturated sandy soil, 
83 and a development of heterogeneity of cementation along 2-m sand column (vertical direction)

84 was observed during treatment.

85 In fact, it is difficult to achieve MICP induced cementation that is highly reproducible and 86 homogeneous via the abovementioned commonly used bio-chemical injection methods. This

87 is because when the bacteria travel through the pore space of soils, they are likely to be

88 filtered through the soil grains with long-linear reduction of microbe concentration along the

89 injection path (Ginn et al. 2002). Furthermore, the attachment of bacteria to porous materials

90 is usually influenced by many physical, chemical and biological factors, and adsorbed

91 bacteria can be remobilized from the soil surface into the liquid phase by flushing of low

92 salinity solutions (Harkes et al. 2010). In the present work, a novel approach using pre-

93 formed urease active crystals, named herein as "bio-slurry", is proposed as a source of urease

94 activity to induce a homogeneous biocementation for soil stabilization. In contrast to the

95 current usually adopted MICP treatment methods, the newly invented bio-slurry treatment

96 approach involves premixing bio-slurry with soil, similar to the traditional cement mixing

97 method, followed by flushing of cementation solution. Compared to the use of bacterial cells,

98 the advantages of using bio-slurry include more uniform and controllable activity

99 distribution, high urease activity retention, and firm attachment against water flushing. In the

100 current study, several parameters in relation to the use of bio-slurry approach for soil

101 stabilization are examined and discussed, including the urease activity retention and

102 distribution, long-term stability, microstructure and $\mathrm{CaCO}_{3}$ content. 


\section{Materials and methods}

\section{Ureolytic bacteria and cementation solution}

108 The urease active bacteria used in the current study were Bacillus sp. strain (DSM 23526)

109 (Al-Thawadi et al. 2012), which were cultivated in a sterile aerobic batch growth medium 110 consisting of $20 \mathrm{~g} / \mathrm{L}$ yeast extract, $0.17 \mathrm{M}$ ammonia sulphate and $0.1 \mathrm{mM} \mathrm{NiCl} 2$, at a $\mathrm{pH}$

111 value of 9.25. The cultivated bacterial culture was collected at the stationary phase of culture 112 growth after 24 hours of cultivation at $28^{\circ} \mathrm{C}$. The optical density $\left(\mathrm{OD}_{600}\right)$ of collected 113 bacterial culture varied between $2-2.5$, and the urease activity was approximately $10 \mathrm{U} / \mathrm{mL}$ (1

$114 \mathrm{U}=1 \mu \mathrm{mol}$ urea hydrolyzed per minute). The culture was stored at $4{ }^{\circ} \mathrm{C}$ refrigerator no longer 115 than two days prior to use. The cementation solution used consisted of $1 \mathrm{M}$ calcium chloride $116(111 \mathrm{~g} / \mathrm{L})$ and $1 \mathrm{M}$ urea $(60 \mathrm{~g} / \mathrm{L})$, and the $\mathrm{pH}$ was found to be between 6.6-6.7.

\section{Bio-slurry preparation}

118 The bio-slurry was prepared by adding specific amounts of urea and calcium chloride (equal

119 moles) into the collected bacterial culture $(100 \mathrm{~mL})$ to reach target concentrations of 50, 100 , $120200,400,600$, and $800 \mathrm{mM}$, followed by stirring at a speed of $600 \mathrm{rpm}$ for about 12 hours.

121 Because of the presence of urea and $\mathrm{Ca}^{2+}$, the $\mathrm{CaCO}_{3}$ crystals were formed due to the urea 122 hydrolysis by the ureolytic bacteria (Fig. 1). The formed crystals were eventually precipitated 123 out of the aqueous phase together with the bacterial cells. When the added urea and $\mathrm{CaCl}_{2}$ 124 were completely consumed, which was determined by measuring the amount of produced 125 ammonia/ammonium in the solution, the mixture was allowed to settle for 6 hours. After 126 settlement, a clean supernatant was disposed and settled crystals (bio-slurry) were then 127 harvested. The produced bio-slurry possessed a solid content of about $15 \pm 1 \%(\mathrm{w} / \mathrm{w})$. The bio- 
128 slurry was produced through $400 \mathrm{mM}$ urea and $\mathrm{CaCl}_{2}$, and was used for long-term stability,

129 microstructure analysis and soil stabilization experiments.

\section{Urease activity measurement}

131 The urease activity of bio-slurry was determined by measuring the urea hydrolysis rate of

132 tested bio-slurry. This was made by recording the change in the ammonium concentration of 133 a mixture consisted of $15 \mathrm{ml} 3 \mathrm{M}$ urea solution, $5 \mathrm{~g}$ bio-slurry (about $15 \%$ solid content) and $13410 \mathrm{ml}$ DI water, over 30 mins. The ammonium concentration was determined using the 135 Nessler method (Greenburg et al. 1992). The specific urease activity of bio-slurry was 136 presented as urease activity per g of completely dried bio-slurry (100\% solid content). For 137 measuring the urease activity along the sand column, about $10 \mathrm{~g}$ of sand was sampled from 138 different locations and added to $30 \mathrm{~mL}$ of urea solution $(1.5 \mathrm{M})$, followed by recording the 139 change in the ammonium concentration over $30 \mathrm{mins}$, as described above. After the urease 140 activity was measured, the sand sample was rinsed with deionized (DI) water and dried at $141105^{\circ} \mathrm{C}$ for 12 hours. The weight of dry sand sample was recorded and the corresponding 142 urease activity was normalized per $\mathrm{g}$ of dry sand.

\section{Soil and cementation method}

144 Pure silica sand (Cook Industrial, Minerals Pty Ltd Western Australia) was selected for the 145 current study, with the following contents: $>0.425 \mathrm{~mm}(0.53 \%) ; 0.3-0.425 \mathrm{~mm}(50.78 \%)$; $146 \quad 0.15-0.3 \mathrm{~mm}(45.96 \%)$; and $<0.15 \mathrm{~mm}(2.73 \%)$. Before the bio-cementation treatment, the 147 sand was premixed with the bio-slurry at a weight ratio of 10:1 (w/w). A standard Proctor 148 compaction test was carried out on the mixture in accordance with the Australian Standards 149 AS 1289.5.4.2-1993 (2000), and a maximum dry density of $16.54 \mathrm{kN} / \mathrm{m}^{3}$ was obtained for the 150 mixture. The sand and bio-slurry were compacted into polyvinyl chloride (PVC) columns of 
151 an inner diameter of $45 \mathrm{~mm}$ until the maximum dry density was reached. PVC columns of

$152300 \mathrm{~mm}$ in height were used to investigate the distribution of urease activity and $\mathrm{CaCO}_{3}$

153 precipitation, whereas PVC columns of $120 \mathrm{~mm}$ in height were used to evaluate the strength

154 improvement during the treatment process. The cementation solution was injected into the

155 sand columns multiple times to reach different cementation levels. Each injection included

1561.1 pore void volume of cementation solution introduced to the sand column from the bottom

157 at a constant flow rate of $30 \mathrm{~mL} / \mathrm{min}$ to generate a constant fully-saturated condition. For

158 field applications, however, flushing can be carried out horizontally between the injection and

159 extraction pipes, where the soil is fully saturated with the fluid, as proposed by van Paassen et

160 al. (2010). Downward vertical flushing using the surface percolation method can also be

161 used, as explained by Cheng and Cord-Ruwisch (2014). After injection was finished, the sand

162 columns were kept at the room temperature $\left(25 \pm 1^{\circ} \mathrm{C}\right)$ for 48 hours to allow for a complete

163 cementation reaction.

\section{Unconfined compressive strength and $\mathrm{CaCO}_{3}$ content determination}

165 The bio-slurry treated sand specimens were flushed with at least five-void volume of tap

166 water to wash away any excess soluble salts prior to the UCS measurements. Before carrying

167 out the UCS tests, the sand samples were dried at $105^{\circ} \mathrm{C}$ for at least 24 hours. According to

168 the procedure reported in the ASTM D2166 (ASTM 2013), the UCS tests were conducted on

169 bio-cemented specimens of selected diameter-to-height ratio of between 1:1.5 and 1:2. The

170 axial load was applied at a constant rate of $1.0 \mathrm{~mm} / \mathrm{min}$.

171 The calcium carbonate content of bio-treated soil samples was determined by adding $20 \mathrm{~mL}$

172 of $2 \mathrm{M}$ hydrochloric acid $(\mathrm{HCl})$ solution into $15-20 \mathrm{~g}$ of dry crushed cemented sample, and

173 the volume of $\mathrm{CO}_{2}$ gas was measured using a U-tube manometer under standard conditions of 
$17425^{\circ} \mathrm{C}$ and $1 \mathrm{~atm}$ (Whiffin et al. 2007). The actual amount of $\mathrm{CaCO}_{3}$ was calculated using an

175 established relationship between the volume of $\mathrm{CO}_{2}$ gas and amount of pure analytical grade

$176 \mathrm{CaCO}_{3}$ powder. It should be noted that, for each sample, measurements of $\mathrm{CaCO}_{3}$ were

177 carried out at least 3 times so as to obtain an average level of $\mathrm{CaCO}_{3}$ precipitation.

\section{Microstructure analysis}

179 To characterize the crystals shape and size of bio-slurry and induced $\mathrm{CaCO}_{3}$ precipitation, 180 and to investigate the bonding behavior between the grain hosts and bio-cemented agent, a 181 microscopy analysis was conducted on dried bio-slurry and cemented soil samples. By

182 knowing exactly how and where the crystals were formed in the grain matrix of bio-cemented 183 soil, it is possible to relate the effectiveness of precipitated $\mathrm{CaCO}_{3}$ crystals to the 184 corresponding obtained UCS values. Before conducting the microscopy investigation, all bio185 cemented soil samples were flushed with tap water and dried at $105^{\circ} \mathrm{C}$ for 24 hours. The 186 microscopy investigation was carried out using the scanning electron microscopy (SEM) 187 (Tescan Mira3 XMU).

\section{Presentation of results}

\section{Effect of concentration of cementation solution on specific urease activity of bio-slurry}

190 In order to find the optimum conditions for bio-slurry production, various concentrations of urea and $\mathrm{CaCl}_{2}$ were used. It can be seen in Fig. 2 that a linear relationship between the total amount of bio-slurry and concentration of urea and $\mathrm{CaCl}_{2}$ was observed. For example, for the $800 \mathrm{mM}$ concentration of urea and $\mathrm{CaCl}_{2}$ about $8 \mathrm{~g}$ of bio-slurry (dry weight) was produced

194 from $100 \mathrm{~mL}$ bacterial culture, which was 16 times higher than that produced using $50 \mathrm{mM}$ 195 concentration. It can also be seen that the bio-slurry produced using different concentrations 
196 of urea and $\mathrm{CaCl}_{2}$ indicated a remarkable difference in terms of the specific urease activity,

197 which is defined as the urease activity per dry weight of bio-slurry. The specific urease 198 activity decreased with the increase in concentration of urea and $\mathrm{CaCl}_{2}$. The maximum 199 specific urease activity (about $1050 \mathrm{U} / \mathrm{g}$ ) was observed when $50 \mathrm{mM}$ concentration was used, 200 which was about 15 times higher than that of the bio-slurry produced using $800 \mathrm{mM}$. This is 201 attributed to the fact that higher concentration of urea and $\mathrm{CaCl}_{2}$ caused larger quantity of 202 crystal precipitation, with possibly thicker layer crystals around the bacterial cells. This thick 203 layer of crystals would reduce the diffusion rate of urea to bacteria. As suggested by Cuthbert 204 et al. (2012), the growth of crystals on the surface of bacterial cells encapsulates the cells 205 leading to a reduction in the ureolysis rate. The loss of urease activity due to encapsulation of 206 crystals was commonly found during MICP process and van Paassen (2009) suggested that 207 the decrease in the bacterial urease activity might be represented by an exponential decay 208 function.

209 It should be noted that although the highest specific urease activity in the present study was 210 obtained using $50 \mathrm{mM}$ of urea and $\mathrm{CaCl}_{2}$, the maximum total urease activity of bio-slurry was 211 obtained using $400 \mathrm{mM}$ concentration. This is due to both the relatively high bio-slurry yield 212 and specific urease activity compared to the bio-slurry produced using other concentrations.

213 It is also worthwhile noting that the optimum concentration of urea and $\mathrm{CaCl}_{2}$ obtained in the 214 current study may not be applicable to other bacterial culture of different urease activity and 215 biomass concentration.

216 Achal et al. (2009) found that the calcite production by the ureolytic bacteria varies

217 depending on the urease activity. Accordingly, a bio-slurry with the same total urease activity 218 might not be able to induce the same amount of $\mathrm{CaCO}_{3}$ precipitation. In order to investigate 219 the efficiency of the $\mathrm{CaCO}_{3}$ production using bio-slurry produced from different 
concentrations of urea and $\mathrm{CaCl}_{2}$, various amounts of bio-slurry of different urease activities

221 were added to an excess amount of $1 \mathrm{M} \mathrm{CaCl}_{2}$ and urea solution $(250 \mathrm{~mL})$. After 48 hours and when no urea hydrolysis reaction was detected (i.e. urease activity decreased to zero), the solution was filtered through $0.45 \mu \mathrm{m}$ filter paper and the amount of crystal was recorded.

The correlation between the added amount of urease activity (U) and amount of induced

$\mathrm{CaCO}_{3}$ crystals is presented in Fig. 3. It can be seen from Fig. 3a that the yield efficiency of

$\mathrm{CaCO}_{3}$ precipitation was decreased using the bio-slurry produced from higher concentration of urea and $\mathrm{CaCl}_{2}$. The bio-slurry produced using $50 \mathrm{mM}$ urea and $\mathrm{CaCl}_{2}$ was recorded to be the most effective to induce $\mathrm{CaCO}_{3}$ precipitation, which was about $0.0312 \mathrm{~g} \mathrm{CaCO}_{3}$ per $1 \mathrm{U}$ urease activity consumed, and was about 3 times more efficient than that produced using 800 $\mathrm{mM}$ concentration. Considering the total urease activity and efficiency of $\mathrm{CaCO}_{3}$ production, the optimum bio-slurry was obtained using $400 \mathrm{mM}$ concentration of urea and $\mathrm{CaCl}_{2}$, which can produce a maximum amount of $\mathrm{CaCO}_{3}$ crystals of about $21.9 \mathrm{~g}$ (see Fig. 3b).

\section{Long-term stability of bio-slurry}

234 The long-term stability of bio-slurry was tested over one month period. During testing, the 235 bio-slurry was stored in a sealed glass bottle at $4^{\circ} \mathrm{C}$. The bio-slurry was then placed at the 236 room temperature for 2 hours prior to measurement of the urease activity. Fig. 4 shows that 237 the decrease in the specific urease activity of bio-slurry is less than $15 \%$ after 27 days of 238 refrigerator storage at $4^{\circ} \mathrm{C}$. This indicates a high stability of bio-slurry at the given specific 239 time.

\section{Microstructure of bio-slurry and induced $\mathrm{CaCO}_{3}$}

241 The micro-features of pure bio-slurry were examined using SEM (see Fig. 5, left column). It

242 can be seen that the bio-slurry was dominant by spherical shape crystals with particle size 
243 around $0.2-5 \mu \mathrm{m}$. There were imprints of the bacterial cells shape at the surface of the

244 spherical crystals (Fig 5b, dashed circles). By simply mixing the pure bio-slurry with the sand

245 without applying a subsequent treatment of cementation solution, no cementation was

246 obtained (data not shown). This suggests that the bio-slurry itself could not provide a bonding

247 force between the sand grains. It was also found that the bio-slurry had high and stable urease

248 activity, and was able to induce crystals precipitation (Figs. 2-4). Therefore, it is fair to

249 assume that, similar to the ureolytic bacteria induced crystal precipitation, the crystals

250 induced by bio-slurry were able to adhere on the sand particle surface, connecting them

251 together and enabling soil strength improvement. Therefore, before applying the bio-slurry

252 approach for soil stabilization, it is worthwhile examining the micro-feature of bio-slurry

253 induced $\mathrm{CaCO}_{3}$ crystals.

254 The bio-slurry induced crystals was prepared by adding $5 \mathrm{~g}$ of bio-slurry produced from 400

$255 \mathrm{mM}$ urea and $\mathrm{CaCl}_{2}$ into $100 \mathrm{~mL}$ of $1 \mathrm{M}$ cementation solution followed by 24 hours reaction

256 period at the room temperature without stirring. The precipitated crystals were filtered using a

257 filtering paper $(0.45 \mu \mathrm{m})$ and was rinsed with DI water, followed by drying at $105^{\circ} \mathrm{C}$ for 24

258 hours. The micro-feature analysis of the bio-slurry induced crystals was presented in Fig. 5

259 (right column). It was found that large rhombohedral crystals of size of around $20 \mu \mathrm{m}$ were

260 observed. These crystals were aggregated together with fine spherical-shape crystals, as

261 indicated by the arrows in Fig. 5(d). This type of rhombohedral crystals was not observed in

262 the pure bio-slurry sample (see Fig. 5, left column). Therefore, it can be concluded that the

263 rhombohedral crystals were induced by the bio-slurry. The absence of the imprints of

264 bacterial cells on the rhombohedral surface suggests that a pure chemical reaction might have

265 occurred to precipitate this type of crystals. This in turn suggests a diffusion mechanism of

$266 \mathrm{CO}_{3}{ }^{2-}$ ions from the inside bacterial cells (where the intercellular urea hydrolysis occurs) to 
267 the surrounding solution which drives the precipitation of such rhombohedral crystals once

268 the critical supersaturation of $\mathrm{Ca}^{2+}$ and $\mathrm{CO}_{3}{ }^{2-}$ was achieved, as discussed by Al-Thawadi and 269 Cord-Ruwisch (2012). According to the literature, the rhombohedral crystals of cubic faces 270 are a typical calcite (De Yoreo and Dove 2004).

\section{Soil stabilization using bio-slurry}

272 Having examined the characteristics of bio-slurry as a carrier of urease activity and inducer of $273 \mathrm{CaCO}_{3}$ precipitation, it is then appropriate to test the soil stabilization using bio-slurry 274 induced $\mathrm{CaCO}_{3}$ precipitation for the purpose of exploring a new manner of ground 275 improvement, as described below.

Improving urease activity retention

277 The retention of urease activity inside the soil is crucial for a successful biocementation. In

278 the present study, the retention of urease activity using bio-slurry was tested. The amount of

279 bio-slurry in the effluent was collected by filtering the effluent using $0.45 \mu \mathrm{m}$ filter paper.

280 After drying at $105^{\circ} \mathrm{C}$, the weight of collected solids was compared with the solid weight of

281 bio-slurry. It was found that, in all tested sand columns, more than $95 \%$ of bio-slurry was

282 retained. It was also interesting to note that although the bio-slurry crystals were well retained

283 within the compacted sand columns, they could be easily separated from the sand grains by

284 re-suspending the mixture in bulk water. This suggests that there was no strong bonding force

285 or notable chemical-physical interaction between the bio-slurry crystals and the sand 286 particles. Therefore, the trapping of fine particles (bio-slurry) in a medium of porous 287 materials (sand grain matrix) was considered to be a mechanical trapping, which was likely to 288 occur at the pore "throat" (contact points) of the sand grains. 
289 It can be seen in Fig. 6 that this type of urease activity retention as a form of bio-slurry cannot

290 be washed out by flushing of the low salinity solution (tap water). The chemical conversion

291 efficiency, which is defined as the percentage of injected urea and $\mathrm{CaCl}_{2}$ that precipitate as

$292 \mathrm{CaCO}_{3}$, was found to decrease from about $98 \%$ to $30 \%$ throughout the MICP process for the

293 control sample (no tap water flushing). In comparison, the chemical conversion efficiency of

294 the sand columns with regular flushing using tap water (i.e. 2-void volume tap water flushed

295 before the $2^{\text {nd }}$ and $4^{\text {th }}$ cementation solution treatments) was only about $10 \%$ less than that

296 achieved for the control sample.

297 For conventional MICP treatment, the fixation of urease active bacteria inside the soil is

298 usually achieved by injecting the bacteria suspension followed by a fixation solution 299 containing $\mathrm{CaCl}_{2}$. However, Harkes et al. (2010) found that flushing a low salinity solution

300 may result in a large portion of fixed bacteria to be remobilized from the solid surface into

301 the liquid phase. On the contrary, the results presented in the current study demonstrate that

302 the use of bio-slurry results in a stable retention of urease activity against the flushing of low

303 salinity water (i.e. tap water), enabling a successful biocementation. This has a potential

304 implication in terms of further extending MICP application to continuous water flow regions,

305 such as control of seepage-induced internal erosion of dams.

306 Improving distribution of urease activity and $\mathrm{CaCO}_{3}$ precipitation

307 After mixing the bio-slurry with sand, a highly uniform distribution of urease activity 308 (variation less than 15\%) along the $300 \mathrm{~mm}$ sand columns was achieved (see Fig. 7a). This

309 homogeneous distribution of urease activity was due to the uniform bio-slurry retention,

310 which was evidenced from the homogeneous distribution of $\mathrm{CaCO}_{3}$ content obtained before

311 the cementation solution treatment (Fig. 7b). After treatment, the distribution of $\mathrm{CaCO}_{3}$ 
312 content (bio-slurry plus bio-slurry induced $\mathrm{CaCO}_{3}$ ) was also detected, as shown in Fig. 7b. It

313 can be seen that the $\mathrm{CaCO}_{3}$ content increased uniformly along the entire sand columns from 3140.016 to $0.035 \mathrm{~g} / \mathrm{g}$ sand for one injection and to $0.054 \mathrm{~g} / \mathrm{g}$ sand for two injections, showing 315 that the variation of $\mathrm{CaCO}_{3}$ content along the sand columns was less than $10 \%$ (the difference 316 between the highest and lowest levels). These results demonstrate that the bio-slurry 317 approach can significantly improve the uniformity of urease activity and distribution of

$318 \mathrm{CaCO}_{3}$. The uniform distribution of crystals after flushing the cementation solution also 319 revealed a stable entrapping of bio-slurry, which assumes that the bio-slurry crystals were not 320 transported and this was evident from the high retention of urease activity.

321 It should be noted that although the current study indicates a uniform $\mathrm{CaCO}_{3}$ content 322 distribution along the $30-\mathrm{cm}$ sand columns, gaining highly uniform distribution at large scale 323 (meters) is still challenging. A uniform distribution of urease activity using the bio-slurry 324 approach is not seemed to be restricted to the distance; however, many other factors can 325 affect the outcomes of $\mathrm{CaCO}_{3}$ content distribution such as the concentration of cementation 326 solution, flow rate, and preferential flow path (Cheng and Cord-Ruwisch 2014; Martinez et al. 327 2013).

\section{Reproducibility of biocementation using bio-slurry}

329 In order for the bio-slurry approach to be a reliable bio-cementation soil stabilization method,

330 it should lead to reproducible and homogeneous bio-treated soils. Fig. 8 shows the stress331 strain curves of two identical sand columns treated equally using the bio-slurry approach. It 332 can be observed that the results of the two samples were quite comparable (both samples 333 followed almost similar failure patterns), indicating a good reproducibility. The peak UCS 
334 values of the two treated specimens were found to be equal to $683 \mathrm{kPa}$ and $716 \mathrm{kPa}$,

335 indicating less than 5\% variation.

336

337

\section{Microstructure of bio-slurry stabilized soils}

Fig. 9 portrays the SEM results of sand particles cemented with $\mathrm{CaCO}_{3}$ crystals induced by the bio-slurry mechanism. Details of the SEM indicate numerous rhombohedral crystals with various sizes ranging from $10-50 \mu \mathrm{m}$. This type of rhombohedral crystals is suggested to be due to the bio-slurry induced crystals (also according to the SEM results presented earlier in Fig. 5). It is interesting to find that the precipitated crystals were dominated at the gaps between the sand grains, whereas the sand grains surface possesses minimum crystals precipitation (see the dash circles in Fig. 9b). This is possibly due to the bio-slurry entrapping at the connecting points of sand grains. It has been suggested in many previous studies that this type of crystals precipitation pattern can effectively bridge the adjacent crystals and provide sufficient inter-particles boding strength (Cheng et al. 2013; Al Qabany et al. 2012; Martinez et al. 2013). The reason that the precipitated crystals are dominating at specific locations (i.e. connecting points) in the bio-slurry treated soils can be explained as follows.

The presence of the bio-slurry crystals can act as nucleation sites for the new $\mathrm{CaCO}_{3}$ crystals formation, by providing existing solid surface, which has lower surface energy than that of the new solute particles (Dirksen and Ring 1991). The bio-slurry crystals hydrolyze urea via the imbedded bacterial cells and release $\mathrm{CO}_{3}{ }^{2-}$ ions into the surrounding solution. The supersaturation degree reaches the highest level on the surface of the bio-slurry crystals and decreases with the distance towards the bulk solution. The existing nucleation sites and high degree of supersaturation favor the precipitation of new $\mathrm{CaCO}_{3}$ crystals on the surface of the bio-slurry crystals. Furthermore, the production of ammonia as a result of the enzymatic urea 
357 hydrolysis creates an alkaline microenvironment around the bio-slurry crystals. The high $\mathrm{pH}$

358 values of these localized areas commence the growth of $\mathrm{CaCO}_{3}$ crystals, similar to the crystal 359 precipitation around the bacterial cells (Stock-Fisher et al. 1999). As discussed earlier, the

360 bio-slurry is most likely to be entrapped at the pore throats (contact points). Therefore, the

361 restricted distribution of bio-slurry enables an induced crystals formation at the particular

362 position and contributes the most to strength development. It is interesting to note that the

363 aggregated spherical shape crystals, which were found in both pure bio-slurry and bio-slurry

364 induced crystal samples (see Fig. 5), were not observed clearly in the cemented soil (see Fig.

365 9). This is probably due attributed to the fact that the bio-slurry attached to the sand surface

366 was gradually covered by the induced rhombohedral crystals during the cementation solution 367 treatment.

Effect of flushes on UCS results

369 As indicated earlier, the development of micro-feature of crystals precipitation was observed

370 during the treatment of cementation solution. It was believed that the regular-shape

371 rhombohedral crystals which appeared during the treatment process would contribute to the

372 strength improvement. In order to evaluate the strength improvement versus the number of

373 cementation solution flushes, UCS tests were conducted for treated soil specimens for various

374 number cementation solution flushes. It was found that the UCS values increased with the

375 increase of the number of flushes (see Fig. 10a). However, it was also found that the rate of

376 strength improvement decreased with the increase of the number of flushes. This can be

377 explained by the gradually decreased chemical conversion efficiency in each flush (Fig. 10a).

378 The decreased chemical conversion efficiency was probably due to the decreased urease

379 activity as a result of the encapsulation of bacterial cells, resulting in a decrease in the amount

380 of crystals precipitation and bridging bond formation. Fig. 10b shows the stress-strain curves 
381 of the bio-slurry treated soils. It can be seen that the stress-strain curves of soil specimens

382 treated with less number of flushes showed a noticeable plastic region, which was not 383 observed for the samples treated with higher number of flushes. In comparison, these soil 384 specimens failed immediately after the maximum stress was reached, indicating a typical 385 mechanical behavior of brittle materials. It was also found that the stiffness of samples 386 (stiffness was represented by Young's modulus obtained from the initial tangent of UCS 387 stress-strain curve) was increased with the number of flushes, which was improved from 7 $388 \mathrm{MPa}$ (1 flush) to $190 \mathrm{MPa}$ (8 flushes).

\section{Discussion}

390 It has been reported in the literature that the urease activity of ureolytic bacteria decreases 391 during the MICP process (Van Paassen et al. 2010; Whiffin et al. 2007). It is also true that the 392 ureolytic bacteria can be active for several flushes of cementation solution before the full loss 393 of urease activity. This suggests that the ureolytic bacteria can survive from the preliminarily 394 precipitated crystals until the bacterial cells are completely encapsulated or died. Based on 395 this phenomenon, a bio-slurry having high urease activity was successfully produced in 396 aqueous medium. In conventional MICP process, multiple injections of bacteria are needed to 397 maintain the urease activity and achieve high level of cementation (Cheng and Cord-Ruwisch 398 2012; Feng and Montoya 2015). However, in the proposed bio-slurry approach, an 399 introduction of different levels of urease activity can be simply achieved by controlling the 400 level of urease activity per amount of soil during the mixing step via regulating the ratio 401 between the bio-slurry and soil.

402 Predicable outcomes of MICP biocementation process are essential for field application. To 403 achieve this, the first step is to know and predict where the bacteria are located in the soil 
404 matrix as the bacteria catalyze the urea hydrolysis to produce cementing agents of $\mathrm{CaCO}_{3}$ 405 crystals. Van Wijngaarden et al. (2012) developed a mathematical model for the fixation of 406 bacteria in MICP bio-cementation process. However, it is a big challenge to use such a model 407 in the field since many important phenomena need to be included such as the advection, 408 dispersion, adsorption, desorption, fixation decay, growth and systematic motion of bacteria 409 (Fontes et al. 1991; Foppen and Schijven 2006). Because of complexity of bacteria 410 distribution, Van Wijngaarden et al. (2010) developed a numerical model to predict behavior 411 of MICP ground improvement based on an assumption of a homogenous distribution of 412 bacteria, which was not likely reachable by the conventional two-phase injection method. 413 Compared with the conventional MICP method, one of the major advantages of the proposed 414 bio-slurry approach is the homogeneous distribution of the bacteria/urease activity 415 distribution, which can be beneficial for establishment of a reliable numerical model that can 416 predict the outcomes of ground improvement more precisely.

417 Controlling the location of crystals precipitation is also crucial to gain an effective strength 418 improvement because only crystals that precipitate at the connecting points can provide 419 enough bonding force among the adjacent soil grains (Cheng et al. 2013; Al Qabany et al. 420 2012; Martinez et al. 2013). Cheng et al. (2013) has achieved a highly effective crystal 421 formation by restricting the crystals precipitation at the particle-particle contact points via 422 controlling the degree of saturation of the cementation solution inside of the soil matrix. 423 However, this method is only applicable to unsaturated soils. In the current study, the SEM 424 images of soils treated by bio-slurry under fully saturated conditions revealed that the 425 induced crystals were dominated at the connecting points, suggesting that the use of bio426 slurry favors an effective crystals formation even in water logging areas. 
427 Future research on this topic may include a thorough investigation on the behavior of bio-

428 slurry using different concentrations of urease activity, uniformity at large scale (meters), and 429 incorporation of bio-slurry method into the real world of deep mixing technology. Another 430 investigation could be the possibility of mixing the bio-slurry and other treatment ingredients 431 with the soil to avoid the repeated injections of cementation solution, which in turn can

432 reduce the field operation cost. However, to achieve a good soil strength using a full mixing 433 methodology, high content of $\mathrm{CaCO}_{3}$ crystals precipitation will be necessary and this will 434 require the highly concentrated cementation solution to provide enough urea and $\mathrm{Ca}^{2+}$ source 435 to form sufficient amount of $\mathrm{CaCO}_{3}$ precipitates. Such highly concentrated $\mathrm{CaCl}_{2}$ and urea 436 solution may dramatically reduce the urease activity, leading to very low efficiency in $\mathrm{CaCO}_{3}$ 437 production and thus poor cementation. Furthermore, the correlation between the soil 438 mechanical response and amount of bio-slurry used is worthwhile an investigation.

\section{Conclusion}

440 This paper presents a novel approach for soil stabilization based on microbially induced 441 carbonate precipitation (MICP) using urease active bio-slurry as catalyzer. By mixing the 442 bio-slurry with sand, more than $95 \%$ of the bio-slurry content was retained and evenly 443 distributed along the soil matrix, leading to a rather uniform $\mathrm{CaCO}_{3}$ precipitation. SEM 444 analysis carried out on bio-slurry treated sand samples revealed that the induced large 445 rhombohedral $\mathrm{CaCO}_{3}$ crystals were localized around the bio-slurry crystals and were also 446 dominated at the connecting points of the sand grains. Through repeated treatments with the 447 cementation solution, the UCS value of bio-slurry treated sand was significantly improved to $4481 \mathrm{MPa}$. 
449 The current study emphasizes the potential use of the newly proposed bio-slurry approach for

450 soil stabilization. As an efficient alternative to the injection method of bacteria-cementation

451 solution, the bio-slurry approach was proved to significantly improve the uniformity of the 452 urease activity and $\mathrm{CaCO}_{3}$ precipitation distribution. The bio-cemented sand columns using 453 the bio-slurry approach resulted in controllable and reproducible outcomes, with an 454 increasing strength by increasing the number of cementation solution flushes.

\section{Acknowledgement}

456 The authors would like to thank Donovan Mujah (PhD candidate) for his assistance in 457 conducting some SEM and UCS tests.

\section{References}

459 Achal, V., and Mukherjee, A. 2015. A review of microbial precipitation for sustainable 460 construction. Construction and Building Materials. 93: 1224-1235. $461 \quad$ doi:10.1016/j.conbuildmat.2015.04.051.

462 Achal, V., Mukherjee, A., Basu, P.C., and Reddy, M.S. 2009. Strain improvement of 463 Sporosarcina pasteurii for enhanced urease and calcite production. Journal of Industrial 464 Microbiology and Biotechnology. 36: 981 -988. doi:10.1007/s10295-009-0578-z.

465 Al-Thawadi, S., and Cord-Ruwisch, R. 2012. Calcium carbonate crystals formation by 466 ureolytic bacteria isolated from Australian soil and sludge. Journal of advanced Science 467 and engineering research. 2(1): 12-26.

468 Al Qabany, A., Soga, K., and Santamarina, C. 2012. Factors affecting efficiency of 469 microbially induced calcite precipitation. Journal of Geotechnical and 470 Geoenvironmental Engineering. 138(8): 992-1001. doi:10.1061/(ASCE)GT.1943$471 \quad 5606.0000666$. 
472 ASTM. 2013. Standard test method for unconfined compressive strength of cohesive soils.

473 ASTM standard D2166. American Society for Testing and Materials, West $474 \quad$ Conshohocken, Pa.

475 AS 1289.5.4.2-1993. 2000. Soil compaction and density tests-compaction control test476 assignment of maximum dry density and optimum moisture content values. Standards 477 Australia International, Strathfield, NSW, 2135.

478 Cheng, L., and Cord-Ruwisch, R. 2014. Upscaling effects of soil improvement by microbially 479 induced calcite precipitation by surface percolation. Geomicrobiology Journal. 31(5): 396-406. doi:10.1080/01490451.2013.836579.

Cheng, L., and Cord-Ruwisch, R. 2012. In situ soil cementation with ureolytic bacteria by surface percolation. Ecological Engineering.

42: $\quad 64-72$. doi:10.1016/j.ecoleng.2012.01.013

Cheng, L., Cord-Ruwisch, R., and Shahin, M.A. 2013. Cementation of sand soil by microbially induced calcite precipitation at various degrees of saturation. Canadian Geotechnical Journal. 50: 81-90. doi:10.1139/cgj-2012-0023.

Cuthbert, M.O., Riley, M.S., Handley-Sidhu, S., Renshaw, J.C., Tobler, D.J., Phoenix, V.R., and Mackay, R. 2012. Controls on the rate of ureolysis and the morphology of carbonate precipitated by S. Pasteurii biofilms and limits due to bacterial encapsulation. Ecological Engineering. 41: 32-40. doi:10.1016/j.ecoleng.2012.01.008

De Yoreo, J.J., and Dove, P.M. 2004. Shaping crystals with biomolecules. Science. 306: 1301.

DeJong, J.T., Mortensen, B.M., Martinez, B.C., and Nelson, D.C. 2010. Bio-mediated soil 494 improvement. Ecological Engineering. 36(2): $197-210$. doi:10.1016/j.ecoleng.2008.12.029. 
496 Dirksen, J.A., and Ring, T.A. 1991. Fundamentals of crystallization: kinetic effects on 497 particle size distributions and morphology. Chemical Engineering Science. 46(10): 498

Feng, K., and Montoya, B.M. 2015. Influence of confinement and cementation level on the 500 behavior of microbial-induced calcite precipitated sands under monotonic drained 501 loading. Journal of Geotechnical and Geoenvironmental Engineering. 04015057-9. doi:10.1061/(ASCE)GT.1943-5606.0001379.

Fontes, D.E., Mills, A.L., Hornberger, G.M., and Herman, J.S. 1991. Physical and chemical factors influencing the transport of microbes through porous media. Applied and Environmental Microbiology. 57(9): 2473-2481.

Foppen, J.W.A., and Schijven, J.F. 2006. Evaluation of data from the literature on the transport and survival of Escherichia coli and thermotolerant coliforms in aquifers under $\begin{array}{llll}\text { saturated } & \text { conditions. } & \text { Water } & \text { Research. }\end{array}$ doi:10.1016/j.watres.2005.11.018.

Ginn, T.R., Wood, B.D., Nelson, K.E., and Scheibe, T.D. 2002. Processes in microbial transport in the natural subsurface. Advances in Water Resources. 25: 1017-1042. doi:10.1016/S0309-1708(02)00046-5.

Greenburg, A.E., Clesceri, L.S., and Eaton, A.D. 1992. Standard Methods for the Examination of Water and Wastewater. 18th ed, American Public Health Association, Washington.

Harkes, M.P., van Paassen, L.A., Booster, J.L., Whiffin, V.S., and van Loosdrecht, M.C.M. 2010. Fixation and distribution of bacterial activity in sand to induce carbonate precipitation for ground reinforcement. Ecological Engineering. 36(2): 112-117. 519 doi:10.1016/j.ecoleng.2009.01.004. 
520 Martinez, B.C., DeJong, J.T., Ginn, T.R., Montoya, B.M., Barkouki, T.H., Hunt, C., Tanyu,

521 B., and Major, D. 2013. Experimental optimization of microbial-induced carbonate 522 precipitation for soil improvement. Journal of Geotechnical and Geoenvironmental 523 Engineering. 139(4): 587-598. doi:10.1061/(ASCE)GT.1943-5606.0000787.

524 Ng, W.S., Lee, M.L., and Hii, S.L. 2012. An overview of the factors affecting microbial525 induced calcite precipitation and its potential application in soil improvement. World 526 Academy of Science, Engineering and Technology. 6: 723-729.

527 Soon, N.W., Lee, L.M., Khun, T.C., and Ling, H.S. 2014. Factors affecting improvement in 528 engineering properties of residual soil through microbial-induced calcite precipitation. 529 Journal of Geotechnical and Geoenvironmental Engineering. 140(5): 04014006-11. $530 \quad$ doi:10.1061/(ASCE)GT.1943-5606.0001089.

531 Stocks-Fischer, S., Galinat, J.K., and Bang, S.S. 1999. Microbiological precipitation of 532 CaCO3. Soil Biology and Biochemistry. 31(11): 1563-1571. doi:10.1016/S0038$533 \quad$ 0717(99)00082-6.

534 van Paassen, L.A. 2009. Biogrout, ground improvement by microbial induced carbonate 535 precipitation. Ph.D. thesis, Delft University of Technology, Delft, the Netherland.

536 van Paassen, L.A., Ghose, R., van der Linden, T., van der Star, W., and van Loosdrecht, M. 537 2010. Quantifying biomediated ground improvement by ureolysis: large-scale biogrout 538 experiment. Journal of Geotechnical and Geoenvironmental Engineering. 136(12): 1721539 1728. doi:10.1061/(ASCE)GT.1943-5606.0000382.

540 van Wijngaarden, W.K., Vermolen, F.J., van Meurs, G.A.M., and Vuik, C. 2012. A 541 mathematical model and analytical solution for the fixation of bacteria in biogrout. 542 Transport in Porous Media. 92(3): 847-866. doi:10.1007/s11242-011-9937-0.

543 van Wijngaarden, W.K., Vermolen, F.J., van Meurs, G.A.M., and Vuik, C. 2010. Modelling 544 the new soil improvement method biogrout: extension to 3D. In Numerical Mathematics 
545 and Advanced Applications, Springer Berlin Heidelberg, Berlin, Heidelberg, pp. 893546 900. doi:10.1007/978-3-642-11795-4_96.

547 Whiffin, V.S., van Paassen, L.A., and Harkes, M.P. 2007. Microbial carbonate precipitation 548 as a soil improvement technique. Geomicrobiology Journal. 24(5): 417-423. 549 doi:10.1080/01490450701436505.

550 


\section{Figure Captions}

552 Fig. 1. Photos of bio-slurry taken during: (a) reaction period; and (b) settling period.

553 Fig. 2. Specific urease activity, total amount of bio-slurry and total amount of urease activity

554 of the bio-slurry produced from $100 \mathrm{~mL}$ of raw bacteiral culture using varied concentrations

555 of urea and $\mathrm{CaCl}_{2}$.

556 Fig. 3. Relationship between: (a) amount of precipitaed $\mathrm{CaCO}_{3}$ crystals and amount of 557 applied urease activity; and (b) total amount of $\mathrm{CaCO}_{3}$ precipiation and different bio-slurries 558 produced from $100 \mathrm{~mL}$ of raw bacteiral culture using varied concentration of urea and $\mathrm{CaCl}_{2}$.

559 Fig. 4. Long-term stability of bio-slurry produced from $400 \mathrm{mM}$ urea and $\mathrm{CaCl}_{2}$.

560 Fig. 5. SEM images of pure bio-slurry produced from $400 \mathrm{mM}$ urea and $\mathrm{CaCl}_{2}$ (left column)

561 and the same bio-slurry with induced $\mathrm{CaCO}_{3}$ precipitation (right column).

562 Fig. 6. Effect of low salinity water flushing (tap water) on chemical conversion efficiency 563 during biocementation process using bio-slurry.

564 Fig. 7. Distribution of: (a) urease activity; and (b) $\mathrm{CaCO}_{3}$ along $300 \mathrm{~mm}$ sand column.

565 Fig. 8. Reproducibility of bio-slurry treated sand with 3 flushes of cementation solution.

566 Fig. 9. SEM images of bio-slurry treated sand samples with 8 flushes of cementation 567 solution.

568 Fig. 10. Effect of flushes of cementation solution on the mechanical response of bio-slurry 569 treated sand: (a) UCS; and (b) stress-strain curves. 

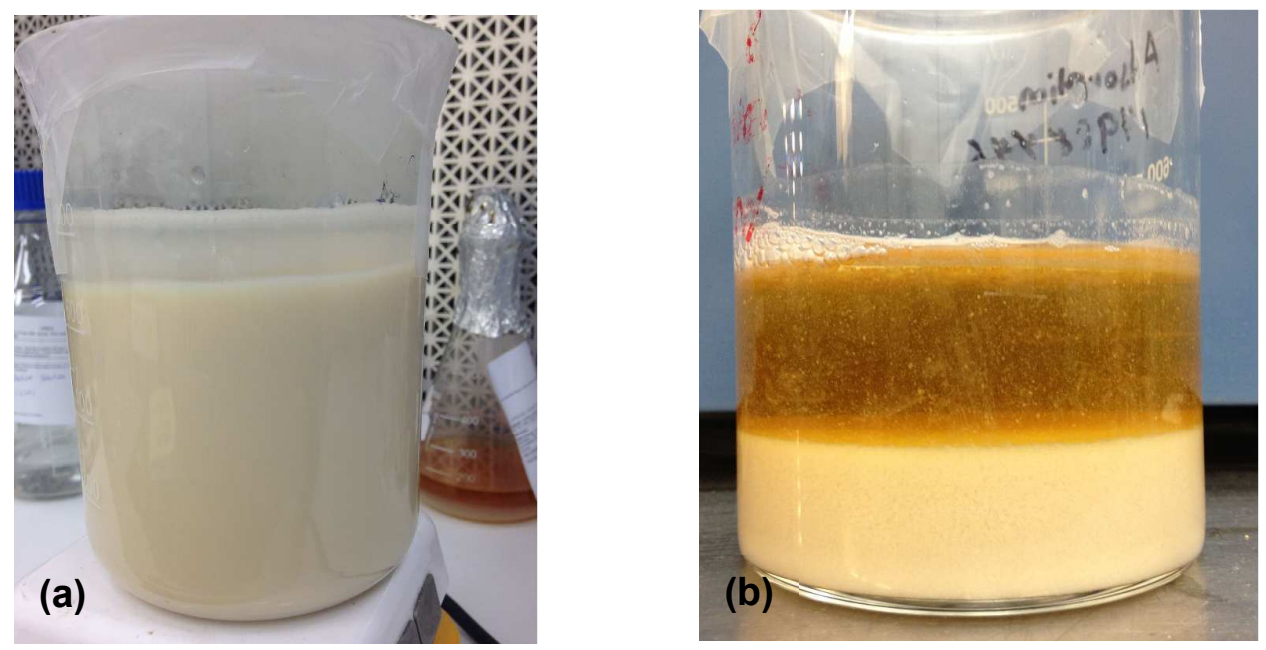

Fig. 1. Photos of bio-slurry taken during: (a) reaction period; and (b) settling period. 


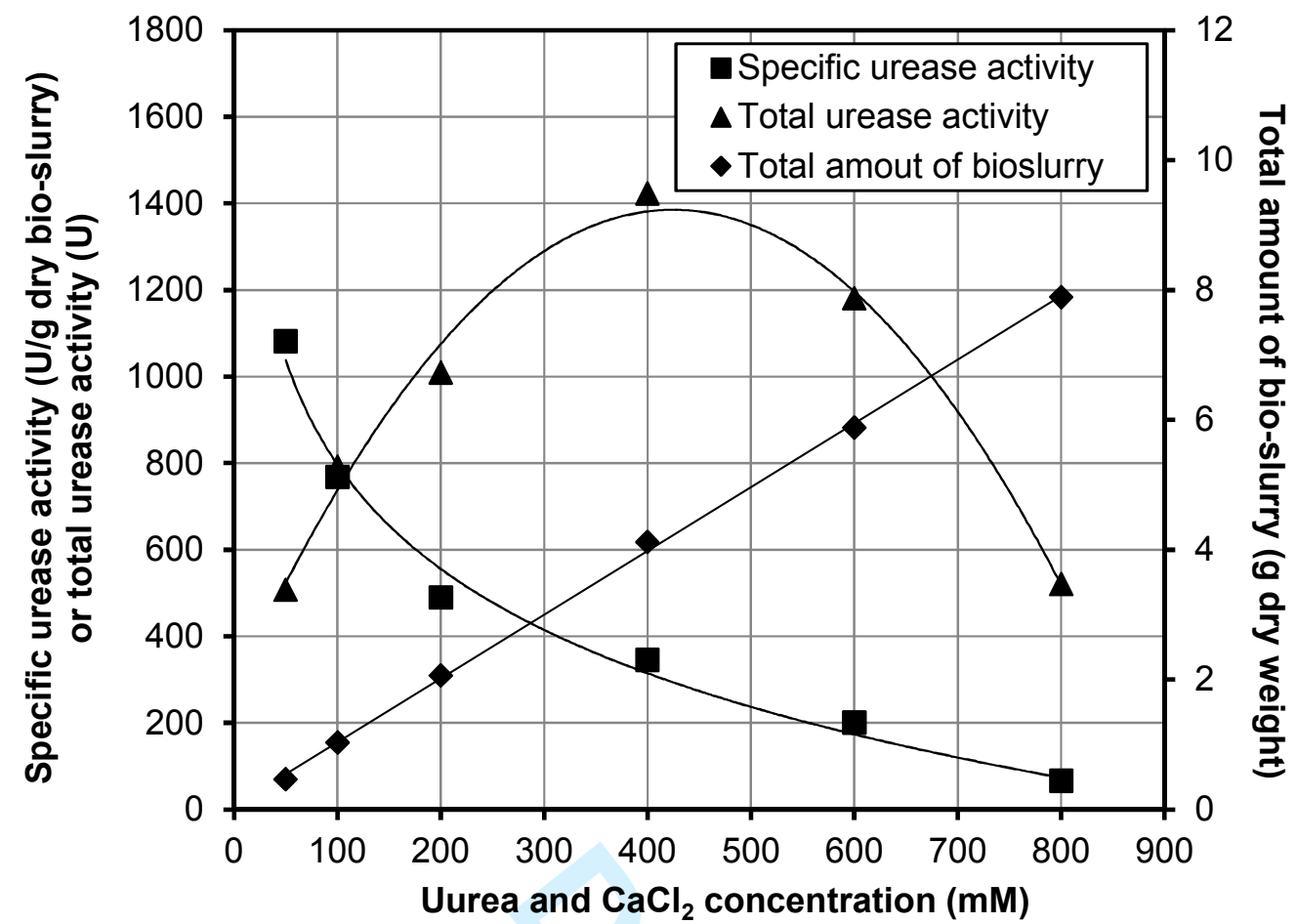

Fig. 2. Specific urease activity, total amount of bio-slurry and total amount of urease activity of the bio-slurry produced from $100 \mathrm{~mL}$ of raw bacteiral culture using varied concentrations of urea and $\mathrm{CaCl}_{2}$. 

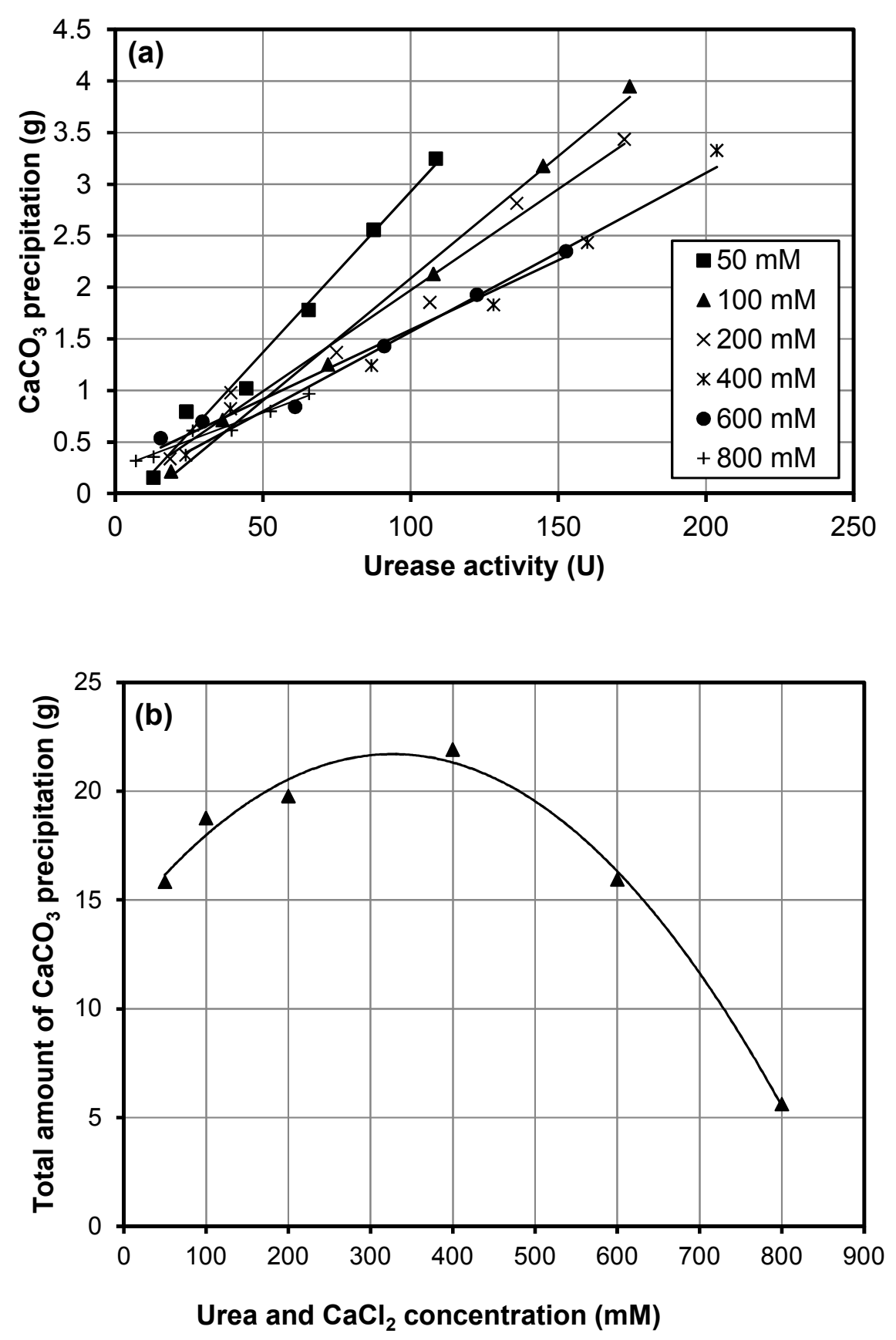

Fig. 3. Relationship between: (a) amount of precipitaed $\mathrm{CaCO}_{3}$ crystals and amount of applied urease activity; and (b) total amount of $\mathrm{CaCO}_{3}$ precipiation and different bio-slurries produced from $100 \mathrm{~mL}$ of raw bacteiral culture using varied concentration of urea and $\mathrm{CaCl}_{2}$. 


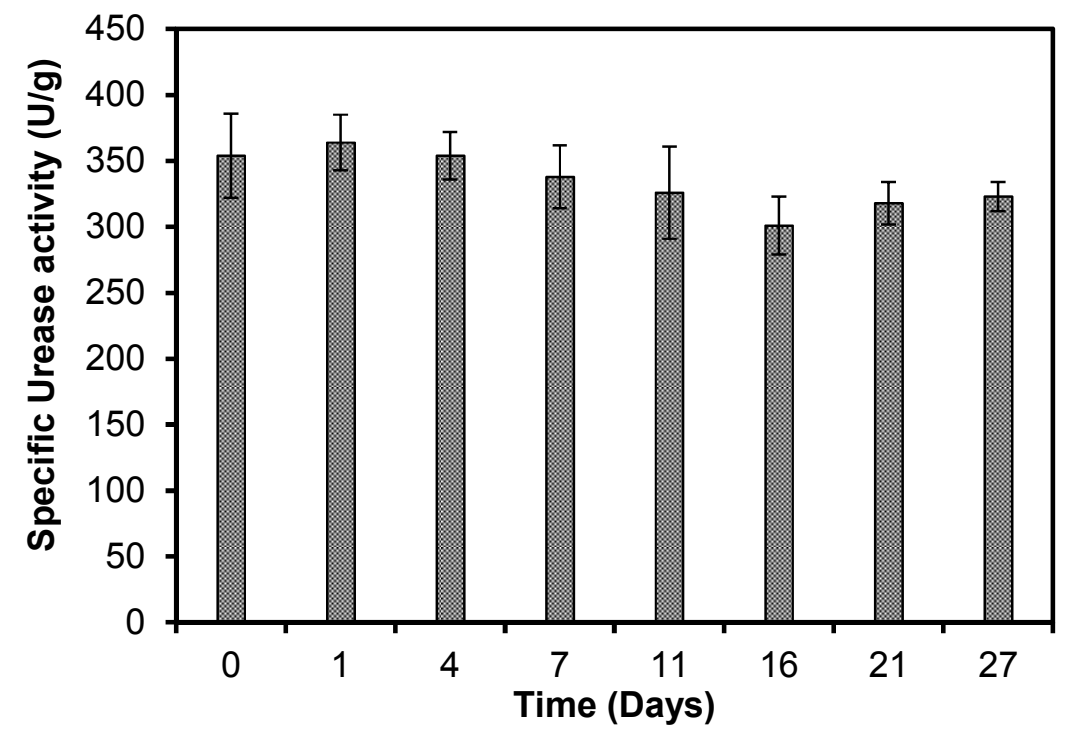

Fig. 4. Long-term stability of bio-slurry produced from $400 \mathrm{mM}$ urea and $\mathrm{CaCl}_{2}$. 

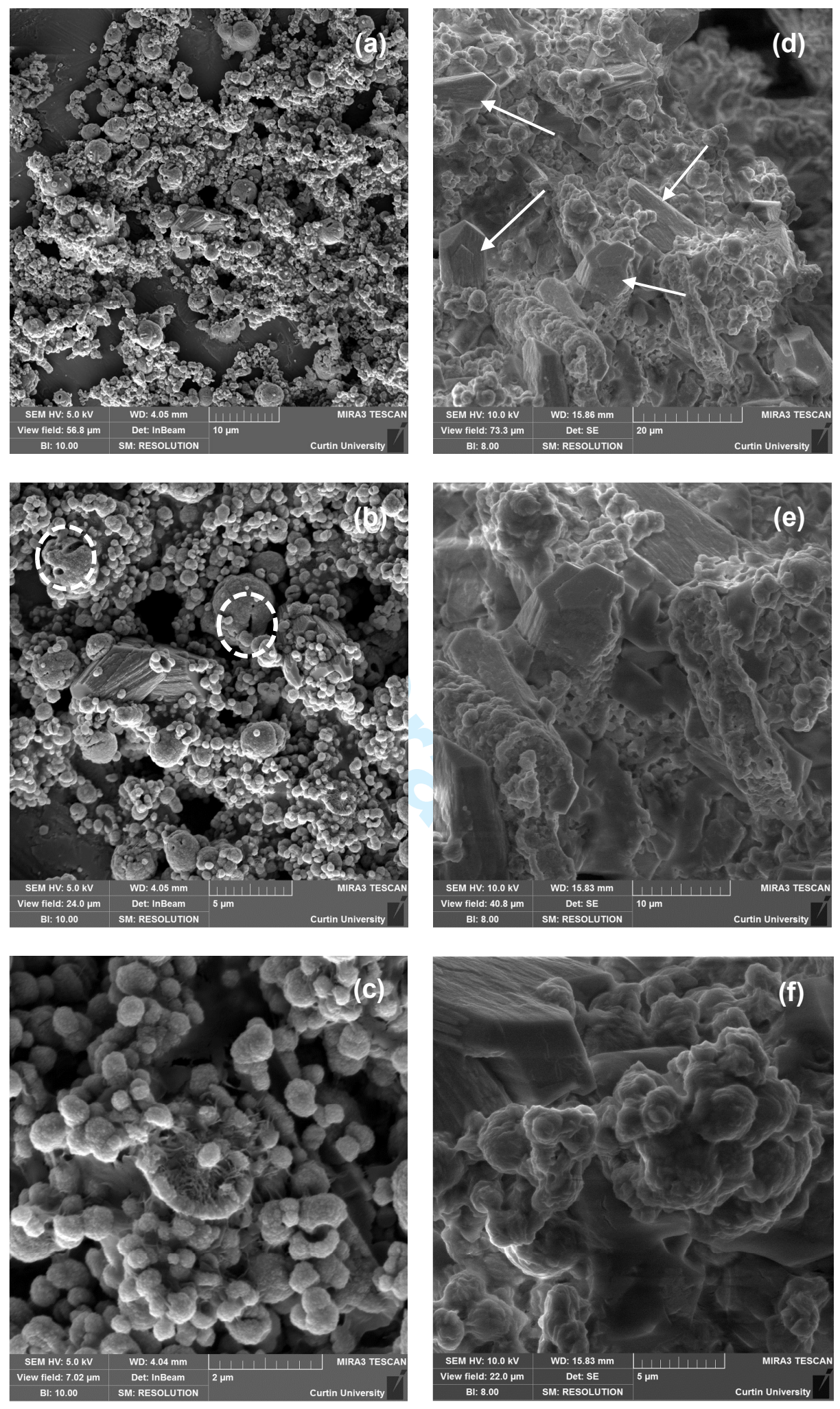

Fig. 5. SEM images of pure bio-slurry produced from $400 \mathrm{mM}$ urea and $\mathrm{CaCl}_{2}$ (left column) and the same bio-slurry with induced $\mathrm{CaCO}_{3}$ precipitation (right column). 


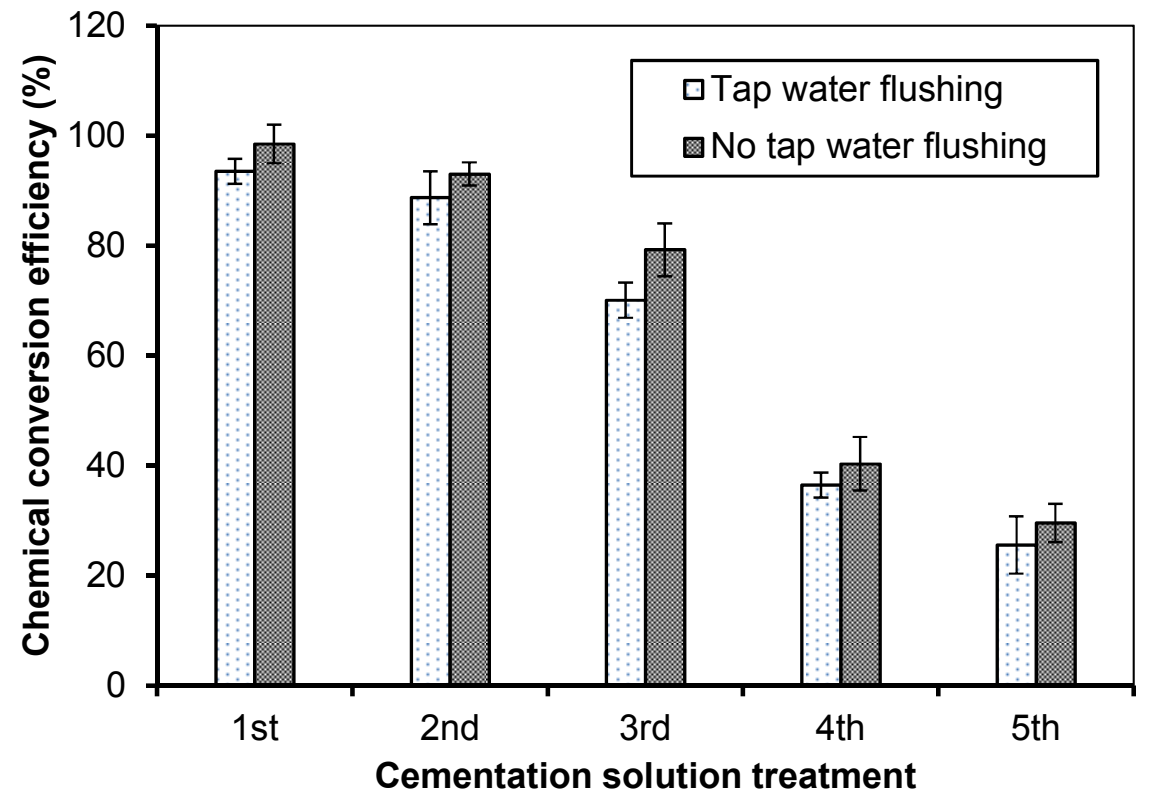

Fig. 6. Effect of low salinity water flushing (tap water) on chemical conversion efficiency during biocementation process using bio-slurry. 

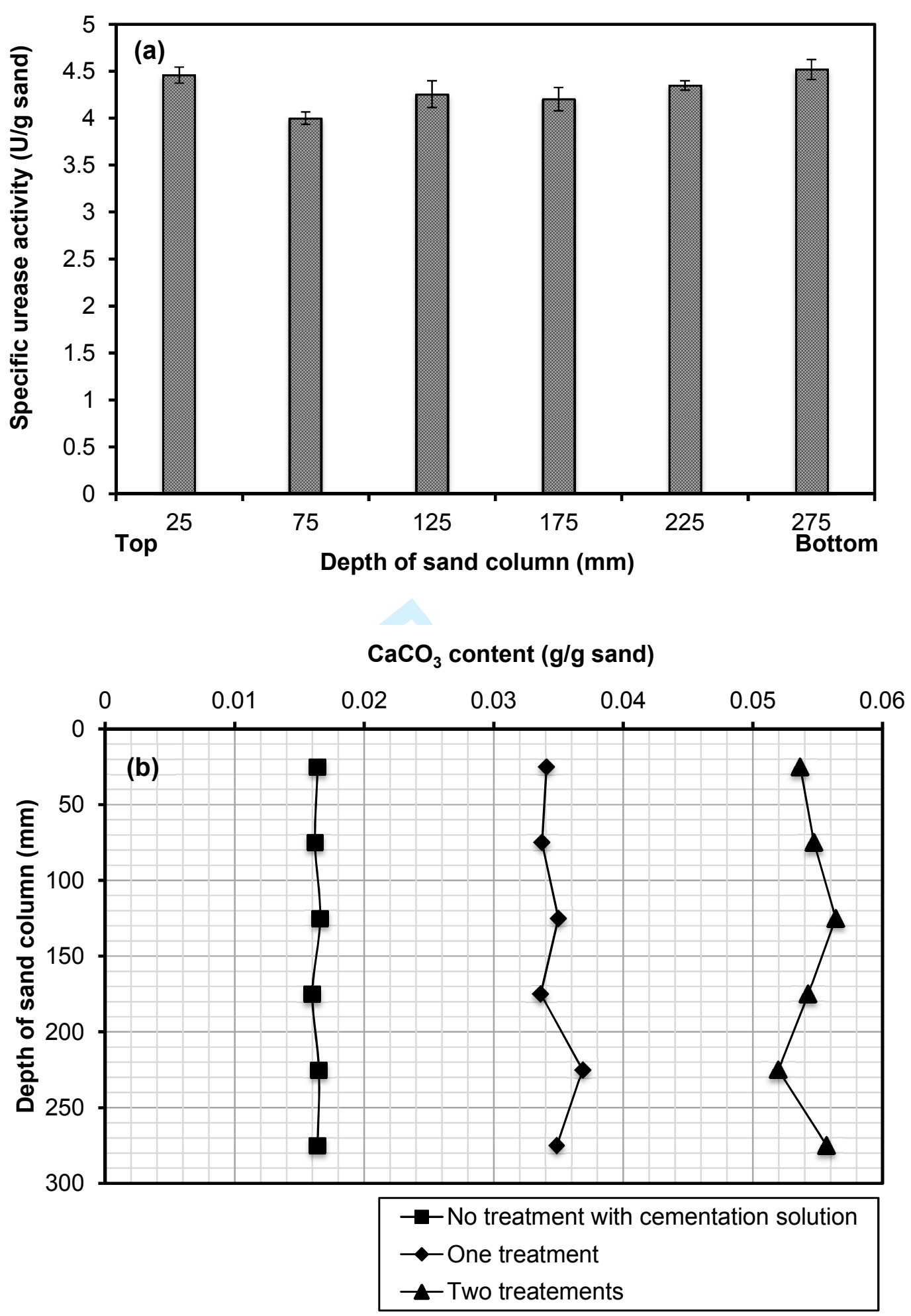

Fig. 7. Distribution of: (a) urease activity; and (b) $\mathrm{CaCO}_{3}$ along $300 \mathrm{~mm}$ sand column. 


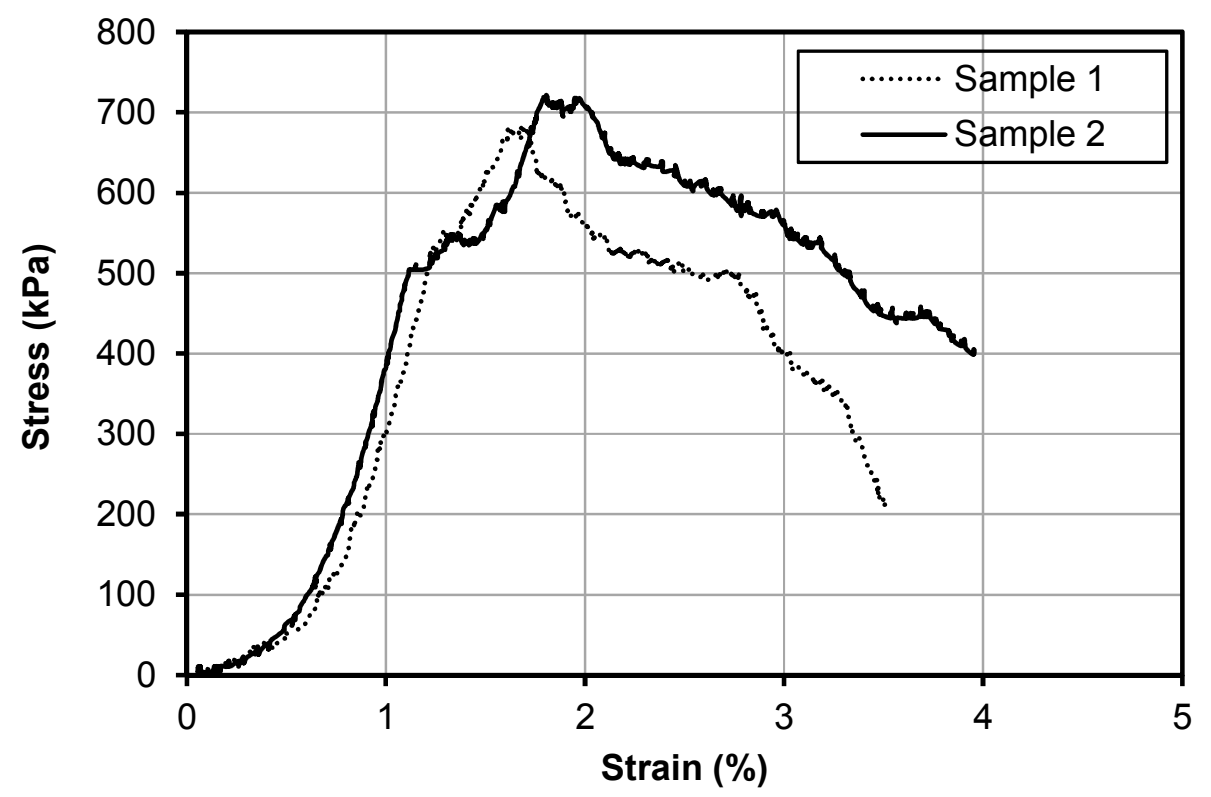

Fig. 8. Reproducibility of bio-slurry treated sand with 3 flushes of cementation solution. 

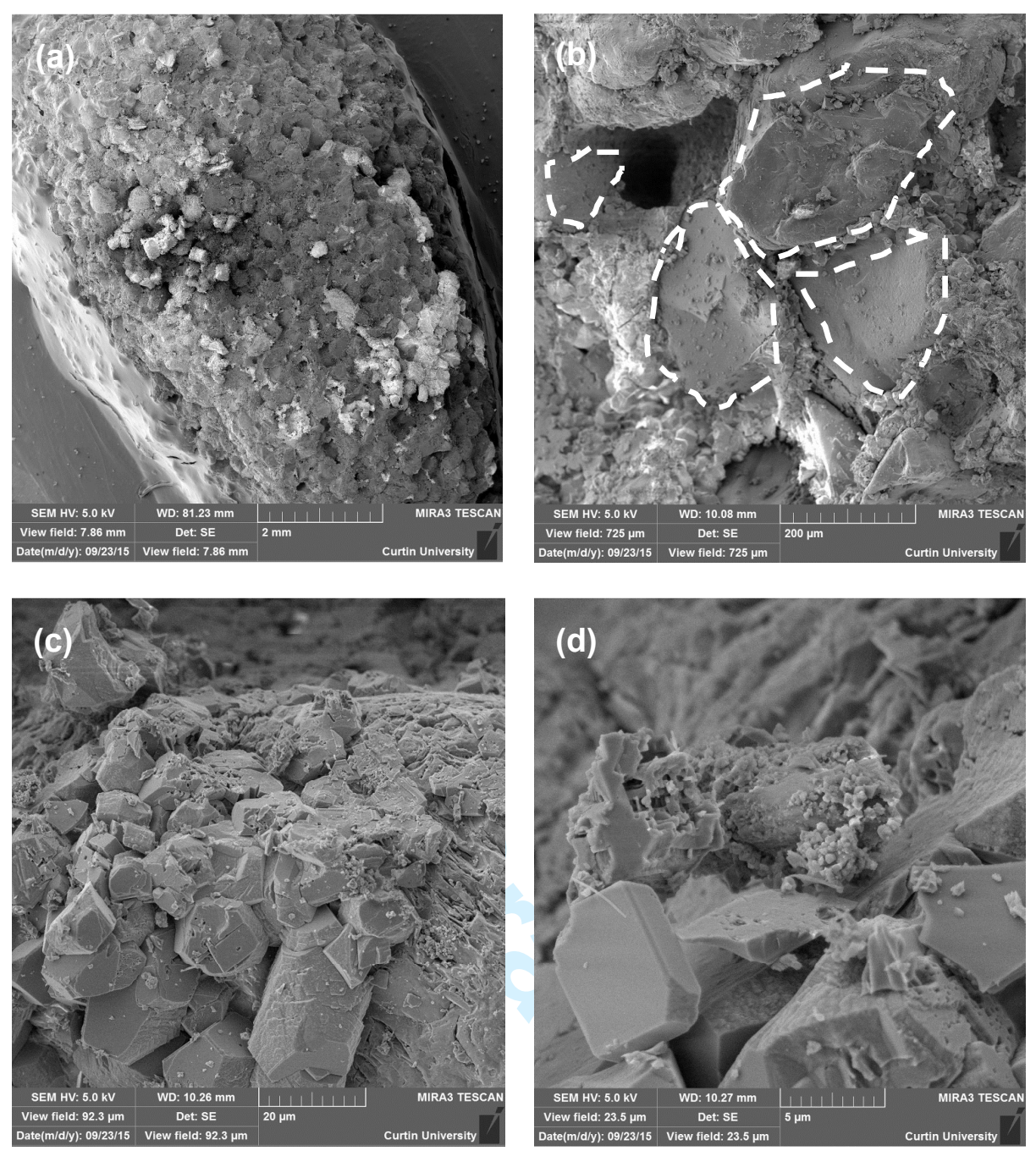

Fig. 9. SEM images of bio-slurry treated sand samples with 8 flushes of cementation solution. 

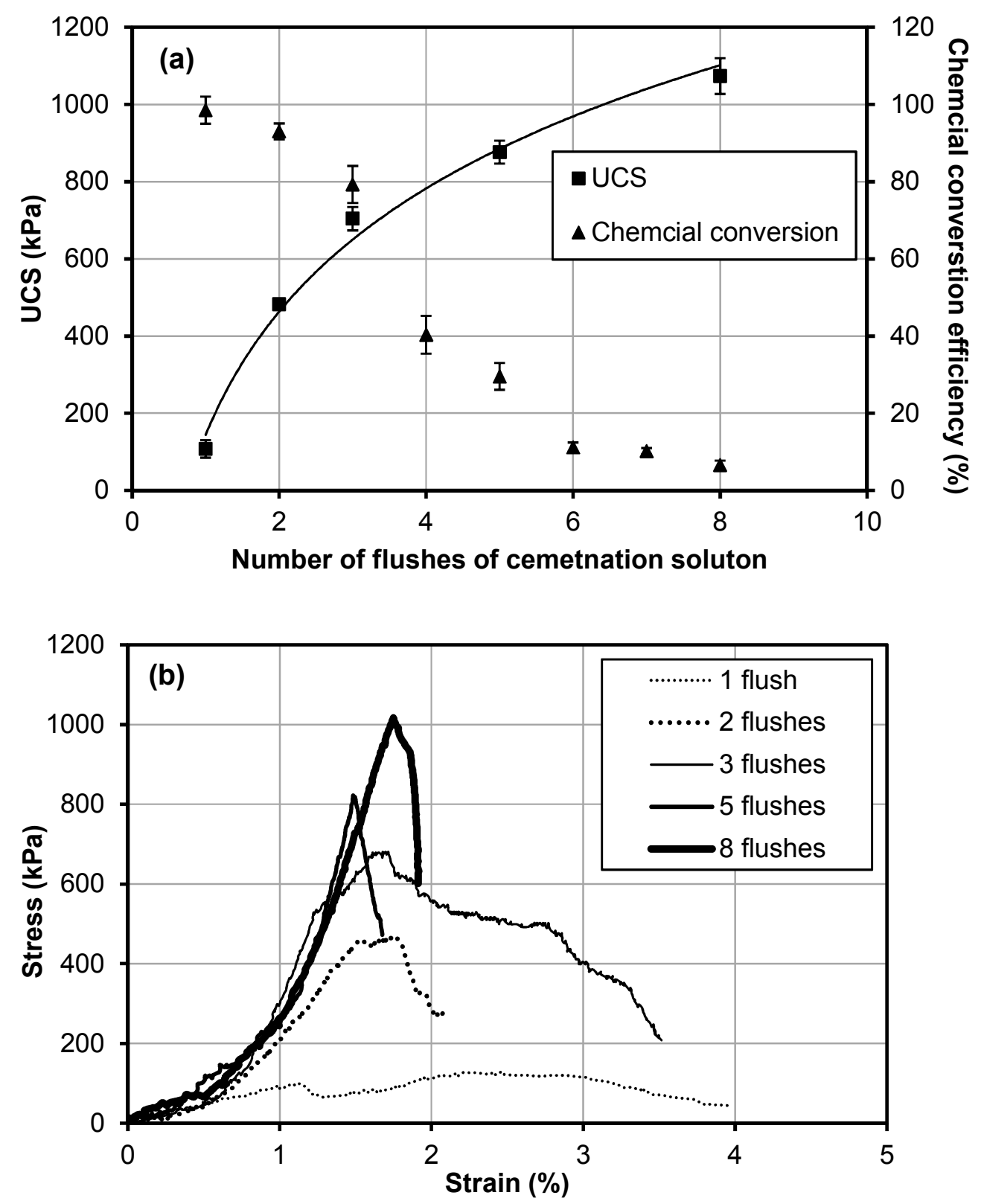

Fig. 10. Effect of flushes of cementation solution on the mechanical response of bio-slurry treated sand: (a) UCS; and (b) stress-strain curves. 